\title{
TINJAUAN FONOLOGIS TERHADAP INTEGRASI PENGGUNAAN NAMA DIRI BAHASA ARAB DI INDONESIA
}

\author{
Ilfiana Iffah Jihada \\ Universitas Muhammadiyah Kupang \\ ilfianaiffahjihada@gmail.com
}

\begin{abstract}
Abstrak
Masyarakat Indonesia lebih banyak memeluk agama Islam, sehingga banyak nama diri dari masyarakat Indonesia yang menggunakan bahasa Arab. Nama diri dalam bahasa Arab di Indonesia banyak terjadi perubahan sistem kebahasaan, baik dalam sistem fonologi. Analisis nama diri berbahasa Arab dalam tataran fonologi menggunakan metode deskriptif kualitatif, di mana penulis mendeskripsikan lalu menganalisis nama-nama diri tersebut dilihat dari tataran fonologi. Sebagai contoh nama diri berbahasa Arab Jamal. Nama diri ini mengalami perubahan fonem yaitu dengan menghilangnya salah satu fonem suprasegmental yaitu tanda panjang (lenght/maddah), yang sebenarnya dalam bahasa Arab جمال dengan transliterasinya Jamaal menjadi Jamal. fenomena seperti yang disebutkan di atas sering terjadi bahkan berulang-ulang dalam penggunaan nama diri berbahasa Arab di Indonesia, sehingga bisa diterima dan terjadilah integrasi.
\end{abstract}

Kata Kunci: Fonologis, Nama diri, Bahasa Arab

\section{Pendahuluan}

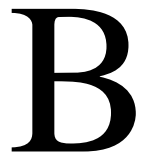
ahasa adalah sistem lambang bunyi yang arbitrer yang dipergunakan oleh masyarakat untuk bekerja sama, berinterkasi dan mengidentifikasikan diri. Bahasa itu harus bersistem, berwujud simbol yang kita lihat dan kita dengar dalam lambang, serta bahasa digunakan oleh masyarakat dalam berkomunikasi. ${ }^{1}$ Suatu bahasa yang memiliki hubungan antara lambang bunyi dengan yang dilambangkan bersifat arbitrer, tetapi penggunaan lambang tersebut untuk suatu konsep bersifat konvensional. Artinya semua anggota masyarakat bahasa itu mematuhi konvensi bahwa lambang tertentu itu digunakan untuk mewakili konsep yang diwakilinya. ${ }^{2}$ Maka dari itu, nama diri bahasa Arab yang dipakai dalam bahasa Indonesia telah dipatuhi oleh masyarakat bahasa Indonesia dalam sistem kebahasaannya. Masyarakat Indonesia lebih banyak memeluk agama Islam, sehingga banyak nama diri dari masyarakat Indonesia yang menggunakan bahasa Arab. Nama diri dalam bahasa tersebut berfungsi sebagai

\footnotetext{
${ }^{1}$ Aslinda, Leni Syafyahya, Pengantar Sosiolongistik (Bandung: Refika Aditama, 2007), 1.

${ }^{2}$ Abdur Chaer, Linguistik Umum (Jakarta: Rineka Cipta, 2007), 47.
} 
identifikasi atau penanda jati diri bahwa mereka adalah pemeluk agama Islam, yang membedakan mereka dengan pemeluk agama lain.

Nama diri dalam bahasa Arab di Indonesia banyak terjadi perubahan sistem kebahasaan, baik dalam sistem fonologi, morfologi, sintaksis, maupun semantik. Perubahan sistem kebahasaan dalam tulisan ini dilihat pada sistem fonologi. Maka, nama diri bahasa Arab dalam bahasa Indonesia mengalami perubahan fonem, bisa terjadi penambahan maupun pengurangan fonem pada nama diri tersebut. Sebagai contoh nama diri berbahasa Arab Jamal. Nama diri ini mengalami perubahan fonem yaitu dengan menghilangnya salah satu fonem suprasegmental yaitu tanda panjang (lenght/maddah), yang sebenarnya dalam bahasa Arab جمال dengan transliterasinya Jamaal menjadi Jamal. fenomena seperti yang disebutkan di atas sering terjadi bahkan berulang-ulang dalam penggunaan nama diri berbahasa Arab di Indonesia, sehingga bisa diterima dan terjadilah integrasi.

Dalam masyarakat yang terbuka, artinya yang para anggotanya dapat menerima kedatangan anggota lain dari masyarakat lain, baik dari satu atau lebih dari satu masyarakat akan terjadi apa yang disebut kontak bahasa. Dari kontak bahasa ini akan terjadi ambil mengambil ataupun saling memindahkan pemakaian unsur-unsur bahasa, dapat pula terjadi percampuran, dan terjadi pemindahan identitas bahasa. ${ }^{3}$ Selain itu, adanya kontak bahasa ini akan terjadi yang disebut dengan bilingualisme dan multingualisme dengan berbagai macam kasusnya seperti interferensi, integrasi, alihkode, dan campurkode. ${ }^{4}$ Pada dasarnya interferensi dan integrasi mempunyai pengertian yang sama, yaitu peristiwa pemakaian unsur bahasa yang satu ke dalam unsur bahasa yang lain terjadi dalam diri si penutur.

Namun keduanya perlu dibedakan karena interferensi merupakan gejala penutur (speech, parole) hanya terjadi pada dwibahasawan dan peristiwanya dianggap sebagai penyimpangan, sedangkan integrasi cenderung sebagai gejala bahasa (language, langue) dapat terjadi pada setiap anggota masyarakat dan peristiwa bukan lagi sebagai penyimpangan karena sudah menyatu dan diterima oleh masyarakat. ${ }^{5}$ Sebenarnya, interferensi tidak perlu terjadi karena unsur-unsur yang sudah diserap sudah ada padanannnya di dalam bahasa penyerap. Berbeda dengan integrasi, kehadirannya memang diharapkan karena unsur-unsur ucapan itu belum atau tidak ada padanannya pada bahasa penyerap sehingga hal ini akan membawa perkembangan pada bahasa yang bersangkutan. Oleh karena itu, tulisan ini akan mengkaji jenis-jenis integrasi dalam penggunaan nama diri bahasa Arab di Indonesia sehingga bisa diterima dalam bahasa Indonesia. Tulisan ini berkaitan

\footnotetext{
${ }^{3}$ Aslinda, Leni Syafyahya, Pengantar Sosiolinguistik...,26.

${ }^{4}$ Abdur Chaer, Linguistik Umum..., 65

${ }^{5}$ Aslinda, Leni Syafyahya, Pengantar Sosiolinguistik..., 65.
} 
dengan dua bahasa yang berbeda, maka untuk menjadikan bahasa pertama itu bisa diambil oleh bahasa kedua, digunakan pendekatan struktural. Artinya melihat bahasa sebagai kumpulan unsur yang satu dengan yang lainnya mempunyai jaringan hubungan, atau sebagai suatu sistem.

\section{Sekilas Tentang Integrasi dan Nama Diri}

Integrasi adalah unsur-unsur bahasa lain yang digunakan dalam bahasa tertentu dan dianggap sudah menjadi warga bahasa tersebut. Penerimaan bahasa lain dalam bahasa tertentu sampai berstatus integrasi memerlukan waktu yang relatif panjang. ${ }^{6}$ Proses penerimaan unsur bahasa lain ke dalam bahasa tertentu awalnya dilakukan secara audial, artinya penutur bahasa tertentu mula-mula mendengarkan kata-kata yang dituturkan oleh penutur aslinya lalu mencoba menggunakannya. Apa yang terdengar oleh telinga, itulah yang diujarkan lalu dituliskan. Oleh karena itu, kosa kata yang diterima secara audial menampakkan ciri ketidakaturan bila dibandingkan dengan kosa kata aslinya. Berbeda jika penerimaan dan penyerapan bahasa lain dilakukan secara visual. Artinya penyerapan dilakukan melalui bentuk tulisan dalam bahasa aslinya, kemudian bentuk itu disesuaikan dengan aturan yang terdapat pada kedua dokumen kebahasaan tersebut. Sehingga kosa kata itu akan nampak teratur.

Dalam proses integrasi unsur serapan itu telah disesuaikan dengan sistem atau kaidah bahasa penyerapnya, sehingga tidak terasa lagi keasingannya. Proses penyesuaian unsur integrasi akan lebih cepat apabila bahasa sumber dengan bahasa penyerapnya memiliki banyak persamaan dibandingkan unsur serapan yang berasal dari bahasa sumber yang sangat berbeda sistem dan kaidahkaidahnya. Integrasi dapat terjadi pada semua tataran bahasa, mulai dari tataran fonologi, morfologi, sintaksis, sampai ketataran leksikon. Tulisan ini akan mengakaji integrasi dalam tataran fonologi, yaitu mengkaji perubahan fonem yang mengalami penambahan maupun pengurangan fonem pada nama diri bahasa Arab dalam bahasa bahasa Indonesia. Adapun mengenai nama diribahwa mempunyai sebuah nama adalah hak istimewa atau kehormatan tiap orang. Nama itu memegang peranan penting dalam hubungan antar manusia. Banyak filosof dan linguis sepakat memandang nama diri itu sebagai markah identifikasi atau penanda jati diri. ${ }^{7}$ Nama diri hanya bermaksud mengidentifikasi seseorang atau sesuatu objek. Oleh karena itu, nama diri yang berkaitan dengan tulisan ini adalah nama orang berbahasa Arab dalam bahasa Indonesia yang berfungsi sebagai penanda identitas seseorang dan tempat.

${ }^{6}$ Aslinda, Leni Syafyahya, Pengantar Sosiolinguistik..., 83.

${ }^{7}$ Stephen Ullmann, Pengantar Semantik (Yogyakarta: Pustaka Pelajar, cet. 1, 2007), 86. 


\section{Istilah Fonologi Dalam Penggunaan Bahasa}

Tuturan bahasa terdiri atas bunyi. Bunyi itu diselidiki oleh fonetik dan fonologi. Fonetik meneliti bunyi bahasa menurut cara pelafalannya dan sifat-sifat akustiknya. Sedangkan fonologi meneliti bunyi bahasa menurut fungsinya. ${ }^{8}$ Fonologi bisa disebut fonemik. Objek penelitian fonemik adalah fonem, yaitu satuan bunyi terkecil suatu bahasa yang berfungsi membedakan makna. Fonem dapat dibagi dua bagian besar, fonem utama dan fonem kedua. Fonem utama adalah sebuah unit bunyi terkecil yang merupakan unsur dari sebuah bentuk ucapan yang mempunyai fungsi tersendiri. Sedangkan fonem kedua adalah sebuah fenomena atau sifat bunyi yang mempunyai fungsi dalam ungkapan ketika diucapkan bersambung dengankata-kata yang lain. ${ }^{9}$ Fonem utama disebut sebagai fonem segmental, sedangkan fonem kedua disebut sebagai fonem suprasegmental.

Fonem segmental didasarkan pada pola pengklasifikasian bunyi yang biasa dilakukan oleh fonetis. Dengan demikian pengklasifikasiannya bisa memanfaatkan bunyi vokoid dan bunyi kontoid atau biasa disebut bunyi vokal dan konsonan. ${ }^{10}$ Adapun bunyi vokal bahasa Arab sebagai berikut.

\begin{tabular}{|c|c|c|c|}
\hline Jenis Vokal & Tipis & Semi tebal & Tebal \\
\hline Kasrah pendek & $\mathrm{I}$ & $\mathrm{I}$ & $\mathrm{I}$ \\
\hline Kasrah panjang & $\mathrm{Ii}$ & $\mathrm{Ii}$ & $\mathrm{Ii}$ \\
\hline Fathah pendek & $\mathrm{A}$ & $\mathrm{A}$ & $Æ$ \\
\hline Fathah panjang & $\mathrm{A}$ & $\mathrm{Aa}$ & $Æ æ$ \\
\hline Dhammah pendek & $\mathrm{U}$ & $\mathrm{U}$ & $\mathrm{C}$ \\
\hline Dhammah panjang & $\mathrm{Uu}$ & $\mathrm{Uu}$ & $\mathrm{Cc}$ \\
\hline
\end{tabular}

Fonem vokal dalam bahasa Indonesia sebagai berikut.

\begin{tabular}{|c|c|c|c|}
\hline & Depan & Tengah & Belakang \\
\hline Tinggi & I & & U \\
\hline Sedang & E & G & O \\
\hline Rendah & & A & \\
\hline
\end{tabular}

Fonem konsonan dalam bahasa Arab dan bahasa Indonesia sebagai berikut.

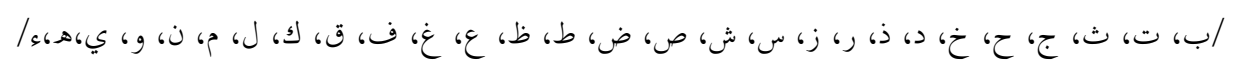

(b, t, ts, j, h, kh, d, dz, r, z, s, sy, sh, dh, th, zh, ', gh, f, q, k, l, m, n, w, y, h, ').

Di antara unsur-unsur bunyi suprasegmental adalah tekanan, intonasi, waqaf, dan panjang pendek. Namun yang berkaitan dengan analisis penggunaan

${ }^{8}$ J.W.M. Verhaar, Asas-asas Linguistik Umum (Yogyakarta: Gadjah Mada University Press, 1996), 10.

${ }^{9}$ Ahmad Sayuti Anshari Nasution, Bunyi bahasa (Jakarta: Amzah, 2009), 121.

${ }^{10}$ Masnur Muslich, Fonologi Bahasa Indonesia: Tinjauan Deskriptif Sistem Bunyi Bahasa Indonesia (Jakarta: Bumi Aksara, cet. 3, 2010), 94. 
nama diri bahasa Arab dalam bahasa Indonesia adalah waqaf dan panjang pendek. Waqaf adalah tempat berhenti sejenak diantara kata-kata atau penggelan kata dalam suatu proses bicara atau melesapkan penanda kasus (a/an, i/in, dan u/un) di akhir kata yang jatuh pada fonem konsonan. Sedangkan pemanjangan (length/mad) merupakan panjang yang bersifat natural, yaitu panjang sudah merupakan sifat bunyi tersebut. Tiga fonem yang disebut dengan huruf mad, yaitu fathah thawilah, kasrah thawilah, dan dhammah thawilah.

\section{Jenis-Jenis Integrasi Dalam Penggunaan Nama Diri Bahasa Arab Di Indonesia}

Pada dasarnya nama diri bahasa Arab dalam bahasa Indonesia mengalami perubahan dalam sistem kebahasaan khususnya sistem fonologi. Namun, karena fenomena tersebut terjadi berulang-ulang dalam tuturan seseorang kemudian disesuaikan dengan sistem bahasa penerimanya, maka terjadilah integrasi. Dalam tulisan ini, akan disebutkan perubahan-perubahan fonem yang telah mengalami penambahan maupun pengurangan yang sudah disesuaikan dengan sistem bahasa penerima, sehingga perubahan fonem tersebut merupakan jenis integrasi dalam penggunaan nama diri bahasa Arab dalam bahasa Indonesia. Dan data yang dijadikan objek dalam tulisan ini adalah nama-nama orang Indonesia yang berbahasa Arab. Namun, karena keterbatasan waktu, nama orang dalam tulisan ini hanya sedikit yang dapat dijadikan objek untuk diteliti.

1) Fatimah Azzahra, jika ditulis dalam bahasa Arab menjadi فاطمة الزهراء /fa>timatu az-zahraa'/. Nama ini mengandung fonem suprasegmental yaitu waqf (pausal). Nama ini menggunakan fonem yang menandakan nomina feminin yang dalam istilah bahasa Arab disebut ta' marbutah yang dilambangkan dengan / // (t) dan ketika mengalami waqf, fonem /t/ berubah menjadi /h/ yaitu /faatimatu/ menjadi /faatimah/ Selain itu, nama ini juga mengalami pemanjangan (lenght/mad). Jika tidak diwaqafkan berbunyi /fatimatu azzahra/.Jadi, penanda nomina feminin dan tanda panjang dalam penulisan bahasa Arab ke bahasa Indonesia merupakan fenomena kebahasaan yang mengalami perubahan fonem. Maka, hal ini telah terintegrasi dalam sistem kebahasaan di Indonesia.

2) khoiriyati, jika ditulis dalam bahasa Arab menjadi_خيريت/khairiyati/. Meskipun bahasa Arab hanya mengenal tiga macam fonem vokal yang merupakan sebagai penanda bunyi dari sebuah fonem (harakat) yaitu /a/ yang ditandai dengan fathah, /i/ dengan kasrah, dan /u/ dengan dammah. Namun dalam bahasa Indonesia ditemukan fonem /o/ yang merupakan alofon dari fonem /a/ yang jatuh setelah fonem konsonan $/ \mathrm{kh} /$. Sehingga yang dalam transliterasinya /khairiyati/ menjadi /khoiriyati/. Maka, substitusi fonem /a/ menjadi /o/ yang terletak setelah fonem konsonan /kh/ merupakan fenomena kebahasaan yang mengalami perubahan fonem /a/ 
menjadi fonem /o/. Hal ini telah terintegrasi dalam sistem kebahasaan di Indonesia.

3) Amar Rohim, jika ditulis dalam bahasa arab menjadi_عمار رحي/2amaar rahiim/. Nama ini mengandung fonem glotal /'/ sebelum fonem /a/ yang pertama, sehingga asalnya /'amar/ dalam bahasa Indonesia menjadi /amar/. Hal ini karena sudah sering terjadi dalam penulisan bahasa Arab ke dalam tulisan bahasa Indonesia. Ada juga fonem suprasegmental seperti penanda bunyi yang mengalami pemanjangan (lenght/mad). Selain itu, nama ini mengalami subsitusi fonem /a/ menjadi /o/ yang merupakan alofon dari fonem /a/ yang jatuh setelah fonem konsonan /r/. Sehingga nama orang yang dalam transliterasinya / rahim/ menjadi /rohim/. Oleh karena itu, nama orang berbahasa Arab dalam bahasa Indonesia telah terintegrasi.Selain tanda panjang (lenght) dan substitusi fonem /a/ menjadi /o/, ada juga pelesapan fonem glotal /'/ sebelum fonem /a/ yang pertama. Hal ini telah terintegrasi dalam sistem kebahasaan di Indonesia.

4) Darul Qolby, jika ditulis dalam bahasa Arab menjadie دار القلب/daarul qalbi/. Nama ini mengandung fonem suprasegmental yaitu mengalami pemanjangan (lenght/mad) pada /daarul/ menjadi /darul/. Selain itu, nama ini mengalami subsitusi fonem /a/ menjadi /o/ yang merupakan alofon dari fonem /a/ yang jatuh setelah fonem konsonan /q/. Sehingga nama ini yang dalam transliterasinya /qalbi/menjadi /qolby/. Nama ini juga mengandung semi vokal palatal /y/, yang mana /y/ merupakan pengganti dari vokal /i/ karena bunyi $/ y /$ terdapat ciri-ciri vokoid dan kontoid. Hal ini telah terintegrasi dalam sistem kebahasaan di Indonesia.

5) Muhammad Abdul Qohar. Nama ini dalam bahasa Arab ditulis محد عبد القهار /muhammad abdu alqaha>r/. nama ini mengalami subsitusi fonem /a/ menjadi /o/ yang merupakan alofon dari fonem /a/ yang jatuh setelah fonem konsonan /q/. Sehingga nama orang yang dalam transliterasinya lqahhaarl menjadi lqoharl. Nama ini juga mengandung fonem suprasegmental yaitu mengalami pemanjangan (lenght/mad) pada /qahhaar/ menjadi /qohar/.

6) Moh. Azhari. Kata Moh. merupakan abreviasi dari mohammad yang mengadaptasi dari nama nabi umat Islam tertulis Muhammad, yakni fonem /o/ diubah menjadi /u/ karena bentuk aslinya adalah محمد dengan harakat dhammah /u/. Dan azhari dalam bahasa arab ditulis أزهر /azhar/. Nama ini sudah terintegrasi.

7) Ghofur. Nama ini dalam bahasa arab ditulis غفور /ghafuur/. Nama ini mengandung fonem suprasegmental seperti tanda panjang (lenght/mad) dan mengalami subsitusi fonem /a/ menjadi /o/ yang merupakan alofon dari fonem /a/ yang jatuh setelah fonem konsonan /gh/. Hal ini merupakan 
perubahan fonem yang terjadi pada nama diri bahasa Arab dalam bahasa Indonesia. Maka, fenomena tersebut telah terintegrasi dalam sistem kebahasaan di Indonesia.

8) Adam Mustaqim. Nama ini ditulis dalam bahasa Arab آدم مسنقيم/aadam mustakiim/. Nama ini mengandung fonem glotal /'/ sebelum fonem /a/ yang pertama, sehingga asalnya /'aadam / dalam bahasa Indonesia menjadi /adam/. Ada juga fonem suprasegmental seperti penanda bunyi yang mengalami pemanjangan (lenght/mad) pada kata /aadam / menjadi /adam/ dan /mustakiim / menjadi /mustakim/.

9) Rokhatun Nikmah. nama ini mengalami subsitusi fonem /a/ menjadi /o/ yang merupakan alofon dari fonem /a/ yang jatuh setelah fonem konsonan /r/. Sehingga nama orang yang dalam transliterasinya /rakhatun/ menjadi /rokhatun/. Selain itu, nama ini menggunakan fonem yang menandakan nomina feminin yang dalam istilah bahasa Arab disebut $t a$ ' marbutah yang dilambangkan dengan /:/ (t) dan ketika mengalami waqf, fonem /t/ berubah menjadi /h/. Jika tidak diwaqafkan berbunyi /rokhatun nikmatu/, namun jika diwaqfkan berbunyi /rokhatun nikmah/. Nama ini juga mengandung fonem glotal di tengah kata /nikmah/ yang ditulis dengan fonem konsonan $/ \mathrm{k} /$ yang seharusnya $/ \%$ Hal ini dikarenakan dalam bahasa Indonesia tidak menggunakan tanda /'/ dan penutur lebih sering mengucapkannya dengan fonem /k/ sehingga ditulis /nikmah/ bukan /ni'mah/.Fenomena seperti ini telah terintegrasi dalam sistem kebahasaan di Indonesia.

10) Ulul Absor. Nama ini mengalami fonem suprasegmental seperti penanda bunyi yang mengalami pemanjangan (lenght/mad) pada kata /uulul / menjadi /ulul/. Selain itu, nama diri ini mengalami subsitusi fonem /a/ menjadi /o/ yang merupakan alofon dari fonem /a/ yang jatuh setelah fonem konsonan /s/. Sehingga nama orang yang dalam transliterasinya labsar/ menjadi labsor/. Fonomena seperti ini telah terintegrasi dalam sistem kebahasaan di Indonesia.

\section{Penutup}

Dari pembahasan di atas, penulis dapat mengambil beberapa kesimpulan, yaitu ada beberapa nama diri berbahasa Arab yang sudah terintegrasi dalam bahasa Indonesia. Integrasi ini terjadi karena adanya perubahan fonem yang mengalami pengurangan maupun penambahan fonem pada nama diri bahasa Arab dalam bahasa Indonesia yang terjadi berulang-ulang dalam tuturan seseorang, kemudian disesuaikan dengan sistem kebahasaannya, sehingga terjadilah integrasi. Hal ini dapat dilihat dari nama diri bahasa Arab di Indonesia yang mengandung fonem suprasegmental seperti penanda bunyi yang mengalami 
pemanjangan (lenght). Seperti /aa/, /ii/, dan /uu/. Selain itu, ada nama diri bahasa Arab di Indonesia yang diawali dengan fonem /'/ (glotal) sebelum fonem /a/ yang pertama. Dalam bahasa arab seperti / $\varepsilon /$ pada awal kata. Ada juga yang mengalami waqf (pausal), seperti /t/ jika diwaqfkan menjadi /h/. Dalam bahasa Arab / $/$. selain itu, ada fonem /a/ menjadi fonem /o/ yang terletak setelah fonem /r/, /kh/, /zh/, /sh/, /dh/, /th/, /s/, dan /gh/. Ada juga fonem semi vokal /y/ yang dihilangkan dan digantikan dengan fonem vokal /i/.

\section{DAFTAR PUSTAKA}

Anshari Nasution, Sayuti Ahmad, Bunyi Bahasa, Jakarta: Amza, 2009.

Aslinda. Syafyahya, Pengantar Sosiolinguistik, Bandung: Refika Aditama, 2007.

Chaer, Abdul, Linguistik Umum, Jakarta: Rineka Cipta, 2007.

Muslich, Masnur, Fonologi Bahasa Indonesia (Tinjauan Deskriptif Sistem Bunyi Bahasa Indonesia), Jakarta: Bumi Aksara, 2010.

Ullmann, Stephen,Pengantar Semantik, Yogyakarta: Pustaka Pelajar, 2007.

Verhaar, J.W.M, Asas-asas Linguistik Umum, Yogyakarta: Gadjah Mada University Press, 1996. 